\title{
Interlaboratory assessment of quantification of SARS-CoV-2 RNA by reverse transcription digital PCR
}

\author{
Chunyan Niu ${ }^{1} \cdot$ Xia Wang ${ }^{1} \cdot$ Yongzhuo Zhang ${ }^{1} \cdot$ Lin Lu $^{2} \cdot$ Di Wang $^{1} \cdot$ Yunhua Gao ${ }^{1} \cdot$ Shangjun Wang ${ }^{3}$. Jingyan Luo ${ }^{4}$. \\ Ying Jiang ${ }^{5} \cdot$ Nuo Wang $^{6} \cdot$ Yong Guo $^{7} \cdot$ Lingxiang Zhu $^{8} \cdot$ Lianhua Dong $^{1}$
}

Received: 19 July 2021 / Revised: 6 September 2021 / Accepted: 20 September 2021 / Published online: 26 October 2021

(C) Springer-Verlag GmbH Germany, part of Springer Nature 2021

\begin{abstract}
The pandemic of the novel coronavirus disease 2019 (COVID-19) has caused severe harm to the health of people all around the world. Molecular detection of the pathogen, severe acute respiratory syndrome coronavirus 2 (SARS-CoV-2), played a crucial role in the control of the disease. Reverse transcription digital PCR (RT-dPCR) has been developed and used in the detection of SARS-CoV-2 RNA as an absolute quantification method. Here, an interlaboratory assessment of quantification of SARS-CoV-2 RNA was organized by the National Institute of Metrology, China (NIMC), using in vitro transcribed RNA samples, among ten laboratories on six different dPCR platforms. Copy number concentrations of three genes of SARS-CoV-2 were measured by all participants. Consistent results were obtained with dispersion within 2.2-fold and CV\% below $23 \%$ among different $\mathrm{dPCR}$ platforms and laboratories, and $Z^{\prime}$ scores of all the reported results being satisfactory. Possible reasons for the dispersion included PCR assays, partition volume, and reverse transcription conditions. This study demonstrated the comparability and applicability of RT-dPCR method for quantification of SARS-CoV-2 RNA and showed the capability of the participating laboratories at SARS-CoV-2 test by RT-dPCR platform.
\end{abstract}

Keywords SARS-CoV-2 $\cdot$ Copy number $\cdot$ RT-dPCR $\cdot$ Quantification

\section{Introduction}

The ongoing coronavirus disease 2019 (COVID-19, originally named 2019-nCoV) pandemic due to severe acute respiratory syndrome coronavirus 2 (SARS-CoV-2) has caused a worldwide health hazard since late 2019 over many countries and

Published in the topical collection Analytical Characterization of Viruses with guest editor Joseph Zaia.

Chunyan Niu and Xia Wang contributed equally to this work.

Lianhua Dong

donglh@nim.ac.cn

1 Center for Advanced Measurement Science, National Institute of Metrology, Beijing, China

2 Center for Reference Materials Research and Management (Office of National Research Center for Certified Reference Materials), National Institute of Metrology, Beijing, China

3 Biological Metrology Center, Nanjing Institute of Measurement and Testing Technology, Nanjing, China

4 R \& D Department, Guangdong Forevergen Medical Technology Co., Ltd, Foshan, China territories [1]. Globally, there have been 207,784,507 confirmed cases of COVID-19 in 20 months after the outbreak, including 4,370,424 deaths, reported to WHO [2]. The pathogen named SARS-CoV-2 is a novel member of the $\beta$ coronavirus genus, with a positive-sense, single-stranded RNA genome of $\sim 30 \mathrm{~kb}$, sharing approximately $50 \%$

5 R \& D Department, Mission Medical Technologies (Ningbo) Co., Ltd, Ningbo, China

6 Key Laboratory of Emerging Pathogens and Biosafety, Centre for Biosafety Mega-Sciences, Wuhan Institute of Virology, Chinese Academy of Sciences, Wuhan, China

7 Department of Biomedical Engineering, School of Medicine, Collaborative Innovation Center for Diagnosis and Treatment of Infectious Diseases, Tsinghua University, Beijing, China

8 TargetingOne Corporation, Beijing, China 
sequence homology with the middle east respiratory syndrome coronavirus (MERS-CoV), 79\% sequence homology with SARS-CoV, and $93.3 \%$ and $96.1 \%$ sequence identity with SARS-like bat coronaviruses RmYN02 from Rhinolophus malayanus and RaTG13 from Rhinolophus affinis [3, 4].

The accurate and timely diagnostic of SARS-CoV-2 is crucial for the control of further disease outbreaks. Reverse transcription quantification real-time PCR (RT-qPCR) was used as the gold standard method to detect SARS-CoV-2 RNA in the infection cases. However, RT-qPCR is a relative quantitative method that uses $C_{\mathrm{q}}$ values to illustrate the initial amount of template in the reaction [5]. This may result in variety when different primer and probe sets or commercial kits are used by operators among different laboratories. Thus, lots of work have been done to evaluate and assess the performance of the RT-qPCR method [6-11].

Furthermore, as a supplement to RT-qPCR, other methods based on PCR have been developed, validated, and evaluated, among which reverse transcription digital PCR (RT-dPCR) has been proposed [12]. Through partitioning the PCR solution into small reactions and applying Poisson statistics to the proportion of the negative partitions, RT-dPCR allows absolute quantification of RNA without depending on standard curves [13, 14]. Moreover, RT-dPCR has the superiority in sensitivity and resistance to inhibitors [13]. Thus, it was reported that RT-dPCR could be used in numerous situations:(1) as a complementary tool for the screening, monitoring, and diagnosis of COVID-19 patients, in particular for patients at a low viral load with ambiguous RT-qPCR results [15-19]; (2) for quantification of the aerodynamic nature of SARS-CoV-2 [20]; (3) for understanding of SARS-CoV-2 gene expression using RT-dPCR assays designed to quantify different target regions spanning genome of SARS-CoV-2 [21]; (4) being resistant to reaction inhibition, for quantification of SARS-CoV-2 viral load from crude lysate without nucleic acid purification [22].

To evaluate the application and improve the wider implementation of RT-dPCR for detection of SARS-CoV-2, some work had been done to compare RT-qPCR and RT-dPCR [23-25]. However, there is not much research to assess the comparability of RT-dPCR between different laboratories and platforms. Inactivated virus particles had been used as a reference standard quantified by RT-dPCR on multiple commercialized platforms, and a CV\% of about $40 \%$ was observed [26]. In order to exclude the effect of the complex extraction step of virus which may introduce extra dispersion to the comparison results, in this study, an interlaboratory assessment on quantification of in vitro transcribed SARS-CoV-2 RNA by RT-dPCR of six different platforms has been organized and analyzed by the National Institute of Metrology, China (NIMC). Participants were requested to measure the copy number concentration of open reading frame (ORF)
$1 \mathrm{ab}$ gene, nucleocapsid $(\mathrm{N})$ gene, and envelope (E) gene. Laboratories could choose to use methods developed by their own or supplied by the organizer, which used SARS-CoV-2 primer and probe sets of World Health Organization (WHO) (for $\mathrm{E}$ gene) and China CDC (for ORF 1ab and $\mathrm{N}$ gene), to demonstrate their capability in the field of SARS-CoV-2 measurement by RT-dPCR.

\section{Materials and methods}

\section{Preparation of SARS-CoV-2 RNA sample}

A mixture of three in vitro transcribed RNA fragments containing ORF, E gene, and $\mathrm{N}$ gene of SARS-CoV-2 was prepared as the comparability study materials.

Sequences containing partial ORF 1ab gene (NC_045512.2, positions 13201-15600), full length $E$ gene, and $\bar{N}$ gene of SARS-CoV-2 were synthesized by BGI (Beijing, China) to generate in vitro transcribed RNA molecules. These sequences were cloned into pBluescript II SK(+) vectors.

The SARS-CoV-2 ORF $1 \mathrm{ab}$ gene, E gene, and $\mathrm{N}$ gene plasmids were linearized with $15 \mathrm{U} / \mu \mathrm{L}$ BamHI (1010S), $10 \times \mathrm{K}$ buffer $(1010 \mathrm{~S}$, both Takara) and nuclease-free water in a final reaction volume of $100 \mu \mathrm{L}$ for $3 \mathrm{~h}$ at $30^{\circ} \mathrm{C}$. The digest was separated by gel electrophoresis and the corresponding bands were purified using the Universal DNA Purification Kit (DP214, Tiangen Biotech (Beijing) Co., Ltd) with $30 \mu \mathrm{L}$ of elution buffer. DNA concentration was estimated using NanoDrop.

To generate positive sense strand RNA, in vitro transcription (IVT) was performed using the MEGAscript T7 kit (AM1334, Thermo Fisher). The mixture contained $7.5 \mathrm{mM}$ of each of ATP, CTP, GTP, and UTP; $1 \times$ reaction buffer; $2 \mu \mathrm{L}$ T7 enzyme mix; and $8 \mu \mathrm{L}$ (approximately 0.2 to $1.1 \mu \mathrm{g}$ ) of plasmid. Incubation was performed at $37^{\circ} \mathrm{C}$ for $4 \mathrm{~h}$ followed by TURBO DNase treatment. The resulting RNA was purified using the MEGAclearTM Kit (AM 1908, Thermo Fisher). RNA transcripts were eluted with $100 \mu \mathrm{L}$ of RNase-free water. Successful in vitro transcription was confirmed by analyzing the 1000-fold dilution using 2100 Bioanalyzer RNA 6000 Pico kit (Agilent) and the nucleic acid concentration was estimated using NanoDrop. Three RNA stock solutions were prepared at approximately $1 \times 10^{10} \mathrm{copy} / \mu \mathrm{L}$ in RNA storage solution (AM7001, Thermo Fisher) and stored at $-70{ }^{\circ} \mathrm{C}$ along with the neat RNA stock. The study material was prepared using the one-step RT-dPCR result as an initial indicator of copy number concentration of ORF 1ab, E gene, and N gene. The three stocks of SARS-CoV-2 RNA transcripts were thawed, mixed, and diluted in RNA storage solution with $5 \mathrm{ng} / \mu \mathrm{L}$ of total RNA extracted from $293 \mathrm{~T}$ human cells. The $293 \mathrm{~T}$ human cell line was purchased from the National Infrastructure of Cell Line Resource and cultured by NIMC. 


\section{Homogeneity of the transcribed RNA sample}

Homogeneity of the study material was assessed by the previously established one-step RT-dPCR method [19] which used the published ORF $1 \mathrm{ab}$ and $\mathrm{N}$ gene assays of the Chinese Center for Disease Control and Prevention and E gene assay of WHO. The primers and probes used are listed in Table S1. Under the same condition, ten units of the study materials were assessed, and three RT-dPCR replicates were analyzed per unit. Homogeneity data was analyzed by ANOVA.

\section{Stability of the transcribed RNA sample}

To determine the stability of the SARS-CoV-2 RNA study material during sample distribution, we performed a short-term stability (STS) study at a range of storage temperatures and times. The RNA samples were maintained at $-70{ }^{\circ} \mathrm{C}$ (reference temperature), $4{ }^{\circ} \mathrm{C}, 27{ }^{\circ} \mathrm{C}$, or on dry ice for 3 and 7 days. Three replicate units were included per condition. Stability was assessed by one-step RT-dPCR mentioned earlier, with measurements of ORF $1 \mathrm{ab}$ and E gene. Three RT-dPCR replicates were analyzed per unit.

The long-term stability (LTS) of the study material was assessed by analyzing the RNA samples after 3,4 , and 9 months of storage, respectively, at the reference storage temperature of $-70{ }^{\circ} \mathrm{C}$. The sampling and analysis methods were the same as STS, except that all the three genes were measured in the LTS study.

\section{Reference value (RV) and uncertainty of transcribed SARS-CoV-2 RNA sample}

The RV of the study material was represented as the copy number concentration of ORF 1ab, E gene, and $\mathrm{N}$ gene of SARS-CoV-2 RNA. The assignments of the copy number values for each gene were carried out at 2 days using the one-step RT-dPCR mentioned earlier by NIMC. Four vials of samples were tested each day with five replicates for each vial.

Uncertainties of SARS-CoV-2 RNA were calculated by taking into account the following factors: characterization of the samples $\left(u_{\text {char }}\right.$, including replicate measurement of target genes, volume of droplet, and calibration of pipettor), homogeneity, and stability of the samples $\left(u_{\mathrm{bb}}\right.$ and $\left.u_{\mathrm{lts}}\right)$. Expand uncertainties $(U)$ were obtained by multiplying standard uncertainty $(u)$ by a coverage factor $(k)$ of 2 using Eq. (1):

$$
U=k \times u
$$

\section{Participants}

Ten laboratories participated in this comparability study and all of the laboratories submitted copy number concentration results of SARS-CoV-2 RNA within the designated time. Two laboratories reported results of two genes (E and N) and other eight laboratories reported results of all three genes. All the participating laboratories are denoted by serial numbers in this paper.

\section{Instrumentation, methods, and reagents of the participants}

A total of six different digital PCR platforms, including QX200 (Bio-Rad, CA, USA), SG-2000 (RainSure, Suzhou, China), Accu ONE (ZhenZhun, Shanghai, China), Drop Maker M1 (TargetingOne, Beijing, China), MicroDrop-100 (Forevergen, Guangdong, China), and DQ24 (Sniper, Suzhou, China), were used by ten laboratories in this comparability study.

For the primer and probe assays, the organizer supplied premix of the three genes (duplex of ORF $1 \mathrm{ab}$ and $\mathrm{E}$ gene, single-target of $\mathrm{N}$ gene) to all the participants, in case for any laboratory being not able to perform the detection due to lack of assays, but they could still choose to use the supplied assays or their own established assays. Of the ten laboratories, the majority $(9 / 10)$ used the supplied assays, with one laboratory using their own established assay.

For the analytical method, nine laboratories employed onestep RT-dPCR approach using kits corresponding to the specific dPCR platforms. One laboratory employed a two-step RT-dPCR approach, where complementary DNA (cDNA) was synthesized in a separate reaction tube prior to dPCR.

All the specific details about the assay performance of the laboratories are listed in Table 1.

\section{Results and discussion}

\section{Assignment and assessment of the study materials}

The study materials consisted of three in vitro transcribed RNA fragments of SARS-CoV-2 ORF 1ab gene, E gene, and $\mathrm{N}$ gene, which are commonly targeted by molecular diagnostic tests, buffered in RNA storage solution with extracted total RNA of 293T human cell line as background. The length, purity, and integrity of each transcript had been checked and confirmed before mixing and preparing.

According to the genome structure of SARS-CoV-2 [27], the length of ORF 1ab, E gene, and N gene is 21,290 nt, $228 \mathrm{nt}$, and $1260 \mathrm{nt}$, respectively. In this study, the transcripts cover the full length of $\mathrm{E}$ gene and $\mathrm{N}$ gene and a partial fragment of ORF $1 \mathrm{ab}$ gene. ORF $1 \mathrm{ab}$ cannot be detected by assays 
Table 1 Summary of the RT-dPCR platforms and methods of the participants

\begin{tabular}{|c|c|c|c|c|c|c|}
\hline ID & Platform & Approach & RT-PCR mix & Primer/probe & $\begin{array}{l}\text { Reaction/ } \\
\text { sample volume }\end{array}$ & Thermal cycling conditions \\
\hline 1 & QX200 & One-Step & $\begin{array}{l}\text { One-Step RT-ddPCR Kit for } \\
\text { Probes (Bio-Rad) }\end{array}$ & $\begin{array}{l}\text { Supplied by } \\
\text { NIMC }\end{array}$ & $20 \mu \mathrm{L} / 3 \mu \mathrm{L}$ & $\begin{array}{l}45^{\circ} \mathrm{C}, 60 \mathrm{~min} ; 95^{\circ} \mathrm{C}, 10 \mathrm{~min} ; 40 \text { cycles of }\left(95^{\circ} \mathrm{C} \text {, }\right. \\
\left.\quad 30 \mathrm{~s}, 56{ }^{\circ} \mathrm{C}, 1 \mathrm{~min}\right) ; 98^{\circ} \mathrm{C}, 10 \mathrm{~min}\end{array}$ \\
\hline 2 & QX200 & One-step & $\begin{array}{l}\text { One-Step RT-ddPCR kit for } \\
\text { Probes (Bio-Rad) }\end{array}$ & $\begin{array}{l}\text { Supplied by } \\
\text { NIMC }\end{array}$ & $20 \mu \mathrm{L} / 4 \mu \mathrm{L}$ & $\begin{array}{l}45^{\circ} \mathrm{C} 10 \mathrm{~min} ; 95^{\circ} \mathrm{C} 3 \mathrm{~min} ; 40 \text { cycles of }\left(95^{\circ} \mathrm{C}\right. \\
\left.15 \mathrm{~s}, 58^{\circ} \mathrm{C} 30 \mathrm{~s}\right) ; 98^{\circ} \mathrm{C} 10 \mathrm{~min}\end{array}$ \\
\hline 3 & QX200 & One-step & $\begin{array}{l}\text { One-Step RT-ddPCR kit for } \\
\text { Probes (Bio-Rad) }\end{array}$ & $\begin{array}{c}\text { Developed by } \\
\text { participant }\end{array}$ & $20 \mu \mathrm{L} / 2 \mu \mathrm{L}$ & $\begin{array}{l}46^{\circ} \mathrm{C} 60 \mathrm{~min} ; 95^{\circ} \mathrm{C} 10 \mathrm{~min} ; 40 \text { cycles of }\left(95^{\circ} \mathrm{C}\right. \\
\left.30 \mathrm{~s}, 58^{\circ} \mathrm{C} 60 \mathrm{~s}\right) ; 98^{\circ} \mathrm{C} 10 \mathrm{~min}\end{array}$ \\
\hline 4 & SG-2000 & One-step & $\begin{array}{l}\text { RT-ddPCR Master Mix for } \\
\text { Probes (RainSure) }\end{array}$ & $\begin{array}{l}\text { Supplied by } \\
\text { NIMC }\end{array}$ & $25 \mu \mathrm{L} / 4 \mu \mathrm{L}$ & $\begin{array}{l}50{ }^{\circ} \mathrm{C} 20 \mathrm{~min} ; 95^{\circ} \mathrm{C} 10 \mathrm{~min} ; 40 \text { cycles of }\left(95^{\circ} \mathrm{C}\right. \\
\left.30 \mathrm{~s}, 55^{\circ} \mathrm{C} 60 \mathrm{~s}\right) ; 98^{\circ} \mathrm{C} 10 \mathrm{~min}\end{array}$ \\
\hline 5 & Accu ONE & Two-step & $\begin{array}{l}\text { DigitalAmp PCR Master Mix } \\
\text { (Zhenzhun) }\end{array}$ & $\begin{array}{l}\text { Supplied by } \\
\text { NIMC }\end{array}$ & $20 \mu \mathrm{L} / 1.25 \mu \mathrm{L}$ & $\begin{array}{l}37{ }^{\circ} \mathrm{C} 20 \mathrm{~min} ; 95^{\circ} \mathrm{C} 10 \mathrm{~min} ; 39 \text { cycles of }\left(95^{\circ} \mathrm{C}\right. \\
\left.30 \mathrm{~s}, 58^{\circ} \mathrm{C} 45 \mathrm{~s}\right)\end{array}$ \\
\hline 6 & $\begin{array}{l}\text { Drop Maker } \\
\text { M1 }\end{array}$ & One-step & $\begin{array}{l}\text { RT-ddPCR Master Mix for } \\
\text { Probes (TargetingOne) }\end{array}$ & $\begin{array}{l}\text { Supplied by } \\
\text { NIMC }\end{array}$ & $30 \mu \mathrm{L} / 1 \mu \mathrm{L}$ & $\begin{array}{l}55^{\circ} \mathrm{C} 15 \mathrm{~min} ; 95^{\circ} \mathrm{C} 10 \mathrm{~min} ; 40 \text { cycles of }\left(95^{\circ} \mathrm{C}\right. \\
\left.30 \mathrm{~s}, 58^{\circ} \mathrm{C} 1 \mathrm{~min}\right) ; 98^{\circ} \mathrm{C} 10 \mathrm{~min}\end{array}$ \\
\hline 7 & MicroDrop-100 & One-step & $\begin{array}{l}\text { One-Step RT-ddPCR mix for } \\
\text { Probes (Forevergen) }\end{array}$ & $\begin{array}{l}\text { Supplied by } \\
\text { NIMC }\end{array}$ & $20 \mu \mathrm{L} / 2 \mu \mathrm{L}$ & $\begin{array}{l}55^{\circ} \mathrm{C} 30 \mathrm{~min} ; 95^{\circ} \mathrm{C} 10 \mathrm{~min} ; 45 \text { cycles of }\left(95^{\circ} \mathrm{C}\right. \\
\left.30 \mathrm{~s}, 60^{\circ} \mathrm{C} 60 \mathrm{~s}\right) ; 98^{\circ} \mathrm{C} 10 \mathrm{~min}\end{array}$ \\
\hline 8 & QX200 & One-step & $\begin{array}{l}\text { One-Step RT-ddPCR kit for } \\
\text { Probes (Bio-Rad) }\end{array}$ & $\begin{array}{l}\text { Supplied by } \\
\text { NIMC }\end{array}$ & $20 \mu \mathrm{L} / 2 \mu \mathrm{L}$ & $\begin{array}{l}42{ }^{\circ} \mathrm{C} 60 \mathrm{~min} ; 95^{\circ} \mathrm{C} 10 \mathrm{~min} ; 40 \text { cycles of }\left(95^{\circ} \mathrm{C}\right. \\
\left.30 \mathrm{~s}, 58^{\circ} \mathrm{C} 60 \mathrm{~s}\right) ; 98^{\circ} \mathrm{C} 10 \mathrm{~min}\end{array}$ \\
\hline 9 & QX200 & One-step & $\begin{array}{l}\text { One-Step RT-ddPCR kit for } \\
\text { Probes (Bio-Rad) }\end{array}$ & $\begin{array}{l}\text { Supplied by } \\
\text { NIMC }\end{array}$ & $20 \mu \mathrm{L} / 4 \mu \mathrm{L}$ & $\begin{array}{l}45^{\circ} \mathrm{C} 10 \mathrm{~min} ; 95^{\circ} \mathrm{C} 5 \mathrm{~min} ; 40 \text { cycles of }\left(95^{\circ} \mathrm{C}\right. \\
\left.15 \mathrm{~s}, 58^{\circ} \mathrm{C} 30 \mathrm{~s}\right) ; 98^{\circ} \mathrm{C} 10 \mathrm{~min}\end{array}$ \\
\hline \multirow[t]{2}{*}{10} & DQ24* & One-step & $\begin{array}{l}\text { One-Step RT-ddPCR kit for } \\
\text { Probes (Bio-Rad) } \\
\text { - E gene }\end{array}$ & $\begin{array}{l}\text { Supplied by } \\
\text { NIMC }\end{array}$ & $20 \mu \mathrm{L} / 4 \mu \mathrm{L}$ & $\begin{array}{l}45^{\circ} \mathrm{C} 10 \mathrm{~min} ; 95^{\circ} \mathrm{C} 5 \mathrm{~min} ; 40 \text { cycles of }\left(95^{\circ} \mathrm{C}\right. \\
\left.15 \mathrm{~s}, 58{ }^{\circ} \mathrm{C} 30 \mathrm{~s}\right) ; 98^{\circ} \mathrm{C} 10 \mathrm{~min}\end{array}$ \\
\hline & & & $\begin{array}{l}\text { One-Step RT-dPCR mix } \\
\text { (Sniper) } \\
\text { - ORF and N gene }\end{array}$ & $\begin{array}{l}\text { Supplied by } \\
\text { NIMC }\end{array}$ & $20 \mu \mathrm{L} / 4 \mu \mathrm{L}$ & $\begin{array}{l}37{ }^{\circ} \mathrm{C} 30 \mathrm{~min} ; 95^{\circ} \mathrm{C} 5 \mathrm{~min} ; 40 \text { cycles of }\left(95^{\circ} \mathrm{C}\right. \\
\left.15 \mathrm{~s}, 58^{\circ} \mathrm{C} 30 \mathrm{~s}\right)\end{array}$ \\
\hline
\end{tabular}

*Two different kits/conditions were used by participant 10

designed out of the location described in the "Preparation of SARS-CoV-2 RNA sample" section.

The copy number concentration values of three genes of SARS-CoV-2 RNA were determined through RT-dPCR [19] by NIMC and denoted as the RVs of the study materials. The RT-dPCR method specifically designed to detect ORF 1ab, E gene, and $\mathrm{N}$ gene was developed by NIMC and had been validated and demonstrated to be applicable to clinical detection of SARS-CoV-2 RNA. Uncertainty of the samples derived from characterization, $u_{\text {char }}$, potential between-unit heterogeneity, $u_{\mathrm{bb}}$, and potential degradation after long-term storage, $u_{\mathrm{lts}}$. The assigned values and uncertainties of the three genes of SARS-CoV-2 RNA are listed in Table 2. The RVs of ORF 1 ab, E gene, and N gene were 2277, 1196, and 1596 copy $/ \mu \mathrm{L}$, respectively; the relative expanded uncertainty $(k=$ 2) values were $14 \%, 17 \%$, and $15 \%$, respectively.

To evaluate the differences in copy number concentration between tubes of the study materials, homogeneity study was carried out using the RT-dPCR method. No significant difference between tubes was observed (Fig. S1) and the samples were thought to be homogeneous enough. Participants were provided with three units of the study materials.

The effect of shipping conditions on copy number concentration of the study materials was assessed through STS study by RT-dPCR. ORF $1 \mathrm{ab}$ and $\mathrm{E}$ gene were measured after being stored at $4{ }^{\circ} \mathrm{C}, 27^{\circ} \mathrm{C}$, and on dry ice for 3 and 7 days. Results showed no systematic effect on copy number concentration (Fig. S2). Thus, the samples were shipped on dry ice and were

Table 2 RVs and uncertainties of the study materials

\begin{tabular}{|c|c|c|c|c|c|c|c|c|}
\hline \multirow[t]{2}{*}{ Gene } & \multirow[t]{2}{*}{$\mathrm{RV}($ copy $/ \mu \mathrm{L})$} & \multicolumn{5}{|c|}{ Relative uncertainty (\%) } & \multirow[t]{2}{*}{$u($ copy $/ \mu \mathrm{L})$} & \multirow[t]{2}{*}{$U(k=2)(\operatorname{copy} / \mu \mathrm{L})$} \\
\hline & & $u_{\text {char,rel }}$ & $u_{\mathrm{bb}, \mathrm{rel}}$ & $u_{\mathrm{lts}, \mathrm{rel}}$ & $u_{\text {rel }}$ & $U_{\text {rel }}(k=2)$ & & \\
\hline ORF $1 \mathrm{ab}$ & 2277 & 2.1 & 0.7 & 6.6 & 7.0 & 14 & 159 & 319 \\
\hline $\mathrm{E}$ & 1196 & 4.2 & 0.9 & 7.0 & 8.3 & 17 & 99 & 199 \\
\hline $\mathrm{N}$ & 1596 & 4.8 & 0.9 & 5.5 & 7.4 & 15 & 118 & 236 \\
\hline
\end{tabular}


ensured to be received within 7 days and under the protection of dry ice. LTS study was carried out to assess the value of the samples after being stored below $-70{ }^{\circ} \mathrm{C}$ for a period of time. No significant change of the value was found for ORF 1ab, E gene, and $\mathrm{N}$ gene after 9 months (Fig. S3).

\section{Copy number concentration results of participants}

\section{Overview of the participants' results}

The participants were required to submit the copy number concentration of SARS-CoV-2 RNA. For ORF 1ab gene, eight of ten laboratories submitted the results; for E gene and $\mathrm{N}$ gene, all the ten laboratories submitted the results. The submitted results and expanded uncertainties $(k=2)$ of the participants are plotted in Fig. 1. Among the ten laboratories, five used Bio-Rad QX200 dPCR platform, and the others used five different dPCR platforms.

For ORF 1ab gene, five laboratories' results agreed with the RV within expanded uncertainty at a $95 \%$ level of confidence, with interlaboratory reproducibility expressed as CV\% of $17 \%$. For E gene, nine laboratories' results agreed with the RV within expanded uncertainty at a $95 \%$ level of confidence with CV\% of $17 \%$. For $\mathrm{N}$ gene, six laboratories' results agreed with the RV within expanded uncertainty at a $95 \%$ level of confidence with CV\% of $23 \%$.

Of the three target genes, $\mathrm{N}$ gene displayed the largest dispersion of the dataset with a ratio of highest to lowest value being 2.2, and ORF $1 \mathrm{ab}$ and $\mathrm{E}$ gene showed a similar ratio of 1.6 and 1.8. The distribution of the participants' results is displayed in Fig. 2. This corresponds a variation less than 1.2 of $C_{\mathrm{q}}$ value in qPCR. The results indicate the quantification results from multiple platforms showed high degree of consistency, although different reagents and protocols were used.

\section{Potential reasons for discrepancies of the results}

Five out of 10 participants used Bio-Rad dPCR platform, and the results of these participants were scattered rather than clustered in Fig. 1. This indicates platform is not the primary reason for the difference of the results. Of the possible reasons which caused dispersion of the results, partition volume is a key factor for the accurate quantification of RNA/DNA by the dPCR method according to Poisson distribution [28]. All the participants used a partition volume designated by the software of each platform. It is thus deduced that calibration of the partition volume may be helpful and necessary to improve the consistence of different dPCR platforms.

The reverse transcription step is another vital factor for quantification of RNA. In this study, One-Step RT-ddPCR Advanced Kit for Probes of Bio-Rad which integrates reverse transcriptase with DNA polymerase in one tube was used by
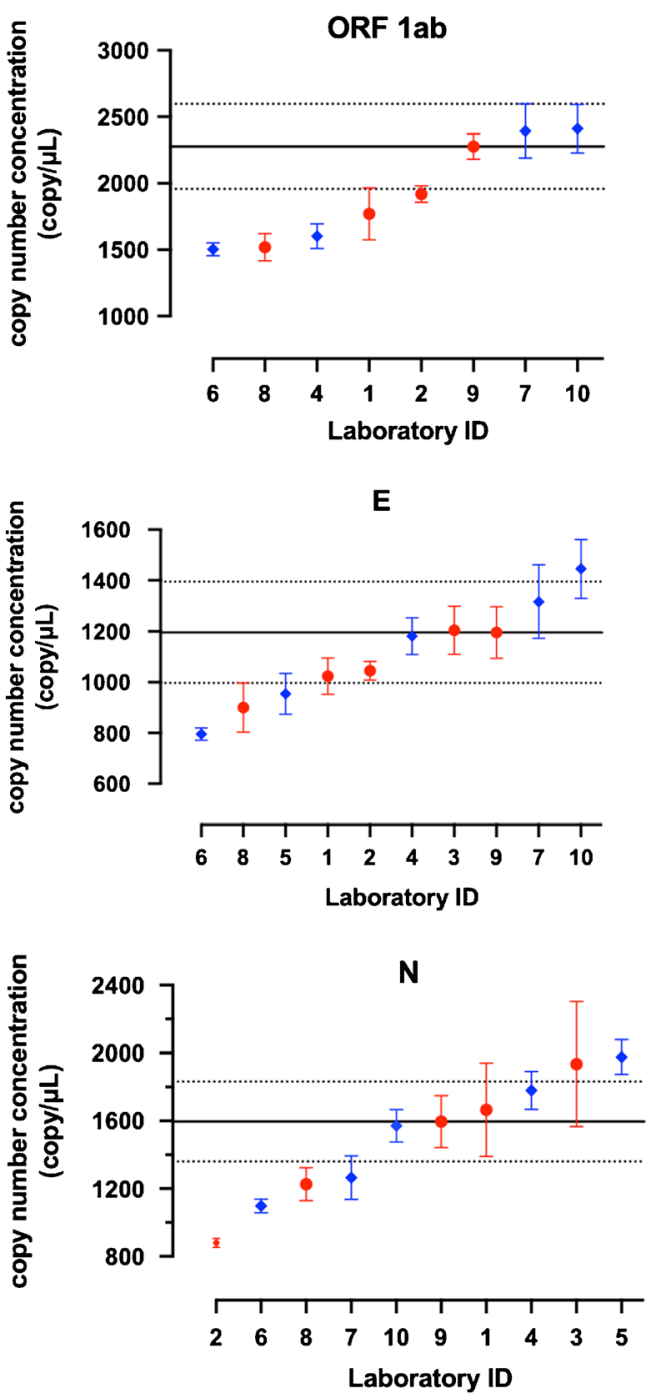

Fig. 1 Participants' results for copy number concentration of SARSCoV-2 RNA ORF 1ab gene, E gene, and N gene. Results of the five laboratories using dPCR platforms of Bio-Rad are indicated with red circle, and results of the five laboratories using other platforms with blue diamond. Solid and dashed horizontal lines indicate RV and expanded uncertainty ( $95 \%$ level of confidence, $k=2$ ) of each gene

laboratories $1,2,3,8$, and 9 . RT temperature of $45^{\circ} \mathrm{C}$ was used by these laboratories except $46^{\circ} \mathrm{C}$ used by laboratory 3 and $42{ }^{\circ} \mathrm{C}$ used by laboratory 8 . It is noted that the result of

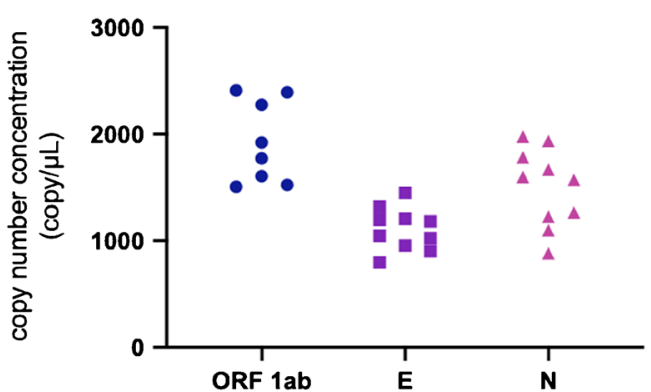

Fig. 2 Scatter diagram showing the copy number concentration of different gene targets obtained from all participants 


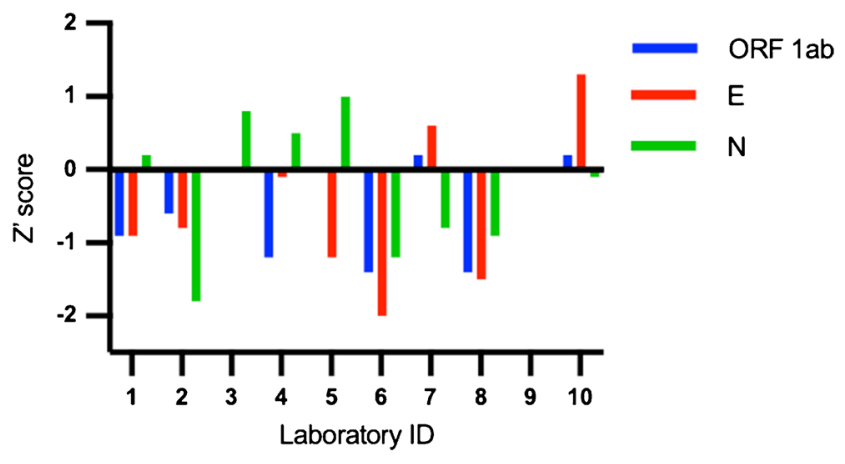

Fig. $3 Z^{\prime}$ scores of the participants

laboratory 8 was significantly lower than that of other labs using the same dPCR platform, which may suggest RT efficiency of One-Step kit of Bio-Rad is higher at RT temperature of $45^{\circ} \mathrm{C}$ than that of $42^{\circ} \mathrm{C}$. This was further investigated by NIMC, by setting RT temperature at $42{ }^{\circ} \mathrm{C}, 45^{\circ} \mathrm{C}, 48^{\circ} \mathrm{C}$, and $50^{\circ} \mathrm{C}$. It is shown that quantification results of both ORF $1 \mathrm{ab}$ and $\mathrm{E}$ gene are slightly higher at $45^{\circ} \mathrm{C}$ than other temperatures (Fig. S4), indicating that $45^{\circ} \mathrm{C}$ may be an optimal RT temperature for one-step RT-ddPCR kit of Bio-Rad. Other laboratories used reverse transcriptases suitable for corresponding platforms, with RT temperature ranging from 37 to $55^{\circ} \mathrm{C}$.

One laboratory (laboratory 5) used a two-step method whose result is the highest for $\mathrm{N}$ gene but rather low for $\mathrm{E}$ gene (result for ORF 1ab gene had not been submitted). Indeed, it is the same case in laboratories 2, 5, and 7, which used a one-step approach. This means one- or two-step approach has no evident impact on the results. However, the deviation varies by genes, due to the different RT and PCR amplification efficiencies of different assays.

Laboratory 10 used one-step RT-dPCR mix of both BioRad (for E gene) and Sniper (for ORF 1ab and N gene), because no positive signals were observed for $\mathrm{E}$ gene using Sniper's mix but normal positive and negative signals were obtained when changing the Sniper mix to Bio-Rad mix. The possible reason may be that the assay of $\mathrm{E}$ gene developed on Bio-Rad dPCR platform was not applicable for reagent of Sniper platform.

Of the two laboratories that did not submit results of ORF 1ab gene, laboratory 3 used assays developed by their own and perhaps the amplification region of primers and probe was not within the genome location of the transcripts; laboratory 5 used assays supplied by NIMC which were developed on QX200 dPCR platform of Bio-Rad and it may not be applicable for Accu ONE dPCR platform of ZhenZhun.

\section{Z' scores of participants' results}

Considering more than one APCR platform was used in the comparability study, the organizer did not supply a standard protocol along with the primers and probes to the participants, including the minimum amount of sample, the thermal cycling conditions, and the reverse transcription strategy. Thus, dispersion of results was unsurprising. In order to evaluate the participants' results by a method determined by the RVs as well as the dispersion of the participants' results, a $Z^{\prime}$ score was introduced to the data analysis [29].

$Z^{\prime}$ score was calculated by Eq. (2):

$Z^{\prime}=\frac{x_{i}-x_{0}}{\sqrt{s^{2}+u_{x}^{2}}}$

where $X_{i}$ is the participant's result, $X_{0}$ is the RV, $s$ is the estimation of the dispersion of the participants' results, and $u_{x}$ is the standard uncertainty of the RV.

$s$ was calculated by Eq. (3):

$s=\mathrm{NIQR}=\mathrm{IQR} \times 0.7413$
Table 3 Summary of the results and $Z^{\prime}$ scores of the participants

\begin{tabular}{|c|c|c|c|c|c|c|c|c|c|}
\hline \multirow[t]{2}{*}{ ID } & \multicolumn{3}{|l|}{ ORF $1 \mathrm{ab}$} & \multicolumn{3}{|l|}{ E } & \multicolumn{3}{|l|}{$\mathrm{N}$} \\
\hline & $\begin{array}{l}\text { Results } \\
(\text { copy } / \mu \mathrm{L})\end{array}$ & $\begin{array}{l}U(k= \\
2)\end{array}$ & $Z^{\prime}$ & $\begin{array}{l}\text { Results } \\
\text { (copy } / \mu \mathrm{L})\end{array}$ & $\begin{array}{l}U(k= \\
2)\end{array}$ & $Z^{\prime}$ & $\begin{array}{l}\text { Results } \\
(\text { copy } / \mu \mathrm{L})\end{array}$ & $\begin{array}{l}U(k= \\
2)\end{array}$ & $Z^{\prime}$ \\
\hline 1 & 1771 & 196 & -0.9 & 1024 & 72 & -0.9 & 1666 & 275 & 0.2 \\
\hline 2 & 1920 & 62 & -0.6 & 1045 & 37 & -0.8 & 880 & 27 & -1.8 \\
\hline 3 & / & / & 1 & 1205 & 95 & 0.0 & 1935 & 369 & 0.8 \\
\hline 4 & 1603 & 93 & -1.2 & 1182 & 73 & -0.1 & 1781 & 112 & 0.5 \\
\hline 5 & / & I & / & 954 & 81 & -1.2 & 1977 & 102 & 1.0 \\
\hline 6 & 1503 & 50 & -1.4 & 796 & 24 & -2.0 & 1098 & 41 & -1.2 \\
\hline 7 & 2394 & 204 & 0.2 & 1317 & 144 & 0.6 & 1265 & 129 & -0.8 \\
\hline 8 & 1520 & 103 & -1.4 & 900 & 97 & -1.5 & 1227 & 98 & -0.9 \\
\hline 9 & 2277 & 96 & 0.0 & 1196 & 102 & 0.0 & 1596 & 154 & 0.0 \\
\hline 10 & 2411 & 182 & 0.2 & 1446 & 115 & 1.3 & 1571 & 96 & -0.1 \\
\hline
\end{tabular}


where NIQR is the normalized interquartile range and IQR is the interquartile range.

This evaluation method depends on uncertainty of the RV and dispersion of all the results.

Assessment of the results followed these principles:

i. The result is as satisfactory when $\left|Z^{\prime}\right| \leqq 2$

ii. The result is ambiguity when $2<\left|Z^{\prime}\right|<3$

iii. The result is not as satisfactory when $\left|Z^{\prime}\right| \geqq 3$.

The $Z^{\prime}$ scores of all the participants for the three target genes are displayed in Fig. 3 and listed in Table 3. For the three target genes, all the participants' results were satisfactory with $\left|Z^{\prime}\right| \leqq 2$. Five laboratories for ORF 1ab gene, six for E gene, and eight for $N$ gene had a $\left|Z^{\prime}\right| \leqq 1$, indicating these laboratories got closer results to RV.

The $Z^{\prime}$ score is a common value to evaluate performance of testing laboratories. The ten laboratories provided consistent result for quantification of copy number concentration of SARS-CoV-2 RNA by RT-dPCR of six different dPCR platforms according to the calculated $\mathrm{Z}^{\prime}$ scores.

\section{Conclusion}

Development of reliable diagnostic methods of SARS-CoV-2 is essential to control the disease spread. The current study provides evidence that the RT-dPCR method using multiple platforms can be applied to measure ORF 1ab, E gene, and N gene of SARSCoV-2 RNA. Using in vitro transcribed RNA as study materials, ten laboratories took part in the interlaboratory comparison study of SARS-CoV-2 RNA. All the reported results were as satisfactory from an evaluation method of $Z^{\prime}$ scores. The dispersion among different $\mathrm{dPCR}$ platforms and laboratories was within 2.2-fold, suggesting RT-dPCR can be potentially considered as a reference method for quantification of SARS-CoV-2 RNA to improve the measurement comparability. The comparison result shows the participating laboratories have developed capability of SARS-CoV-2 test by RT-dPCR platform. Calibration of the partition volume and controlling of the performance, like RT steps under optimum conditions, are required to further improve the interlaboratory comparability of SARS-CoV-2 RNA tests by dPCR platforms.

Supplementary Information The online version contains supplementary material available at https://doi.org/10.1007/s00216-021-03680-2.

Acknowledgements The authors thank the cooperation and support of Nanjing Institute of Measurement and Testing Technology, Guangdong Forevergen Medical Technology Co., Ltd, Mission Medical Technologies (Ningbo) Co., Ltd, Wuhan Institute of Virology, Chinese Academy of Sciences, TargetingOne Corporation, Suzhou RainSure Scientific Co., Ltd, ZhenZhun Bio-technology Co., Ltd, Beijing Center for Physical and Chemical Analysis, and Sniper Medical Technology Co., Ltd.
Funding This study was supported by the National Key Research and Development Program of China (2017YFF0204605) and Special Technical Support Project of State Administration of Market Regulation (2020YJ039).

\section{Declarations}

Conflict of interest The authors declare no competing interests.

\section{References}

1. Dhama K, Khan S, Tiwari R, Sircar S, Bhat S, Malik YS, et al. Coronavirus disease 2019-COVID-19. Clin Microbiol Rev. 2020;33(4)

2. WHO. WHO coronavirus (COVID-19) dashboard. https://covid19. who.int/. 2021.08.18.

3. Zhou H, Chen X, Hu T, Li J, Song H, Liu Y, et al. A novel bat coronavirus closely related to SARS-CoV-2 contains natural insertions at the $\mathrm{S} 1 / \mathrm{S} 2$ cleavage site of the spike protein. Current biology : CB. 2020;30(11):2196-203.e3.

4. Lu R, Zhao X, Li J, Niu P, Yang B, Wu H, et al. Genomic characterisation and epidemiology of 2019 novel coronavirus: implications for virus origins and receptor binding. Lancet. 2020;395(10224):565-74.

5. Livak KJ, Schmittgen TD. Analysis of relative gene expression data using real-time quantitative PCR and the 2(-delta delta $\mathrm{C}(\mathrm{T})$ ) method. Methods. 2001;25(4):402-8.

6. Hu X, Zhu L, Luo Y, Zhao Q, Tan C, Chen X, et al. Evaluation of the clinical performance of single-, dual-, and triple-targetSARSCoV-2RT-qPCR methods. Clinica chimica acta; International Journal of Clinical Chemistry. 2020;511:143-8.

7. Zhen W, Manji R, Smith E, Berry GJ. Comparison of four molecular in vitro diagnostic assays for the detection of SARS-CoV-2 in nasopharyngeal specimens. Journal of clinical microbiology. 2020;58(8).

8. Smith E, Zhen W, Manji R, Schron D, Duong S, Berry GJ. Analytical and clinical comparison of three nucleic acid amplification tests for SARS-CoV-2 detection. Journal of clinical microbiology. 2020;58(9).

9. Zhen W, Smith E, Manji R, Schron D, Berry GJ. Clinical evaluation of three sample-to-answer platforms for detection of SARS-CoV-2. Journal of clinical microbiology. 2020;58(8).

10. Uhteg K, Jarrett J, Richards M, Howard C, Morehead E, Geahr M, et al. Comparing the analytical performance of three SARS-CoV-2 molecular diagnostic assays. Journal of clinical virology : the official publication of the Pan American Society for Clinical Virology. 2020;127:104384.

11. Vogels CBF, Brito AF, Wyllie AL, Fauver JR, Ott IM, Kalinich $\mathrm{CC}$, et al. Analytical sensitivity and efficiency comparisons of SARS-CoV-2RT-qPCR primer-probe sets. Nat Microbiol. 2020;5(10):1299-305.

12. Cassinari K, Alessandri-Gradt E, Chambon P, Charbonnier F, Gracias S, Beaussire L, et al. Assessment of multiplex digital droplet RT-PCR as a diagnostic tool for SARS-CoV-2 detection in nasopharyngeal swabs and saliva samples. Clin Chem 2020.

13. Hindson BJ, Ness KD, Masquelier DA, Belgrader P, Heredia NJ, Makarewicz AJ, et al. High-throughput droplet digital PCR system for absolute quantitation of DNA copy number. Anal Chem. 2011;83(22):8604-10.

14. Hindson CM, Chevillet JR, Briggs HA, Gallichotte EN, Ruf IK, Hindson BJ, et al. Absolute quantification by droplet digital PCR versus analog real-time PCR. Nat Methods. 2013;10(10):1003-5. 
15. de Kock R, Baselmans M, Scharnhorst V, Deiman B. Sensitive detection and quantification of SARS-CoV-2 by multiplex droplet digital RT-PCR. European journal of clinical microbiology \& infectious diseases : official publication of the European Society of Clinical Microbiology. 2021;40(4):807-13.

16. Liu C, Shi Q, Peng M, Lu R, Li H, Cai Y, et al. Evaluation of droplet digital PCR for quantification of SARS-CoV-2 virus in discharged COVID-19 patients. Aging. 2020;12(21):20997-1003.

17. Falzone L, Musso N, Gattuso G, Bongiorno D, Palermo CI, Scalia $\mathrm{G}$, et al. Sensitivity assessment of droplet digital PCR for SARSCoV-2 detection. Int J Mol Med. 2020;46(3):957-64.

18. Suo T, Liu X, Feng J, Guo M, Hu W, Guo D, et al. ddPCR: a more accurate tool for SARS-CoV-2 detection in low viral load specimens. Emerging microbes \& infections. 2020;9(1):1259-68.

19. Dong L, Zhou J, Niu C, Wang Q, Pan Y, Sheng S, et al. Highly accurate and sensitive diagnostic detection of SARS-CoV-2 by digital PCR. Talanta. 2021;224:121726.

20. Liu Y, Ning Z, Chen Y, Guo M, Liu Y, Gali NK, et al. Aerodynamic analysis of SARS-CoV-2 in two Wuhan hospitals. Nature. 2020;582(7813):557-60.

21. Telwatte S, Kumar N, Vallejo-Gracia A, Kumar GR, Lu CM, Ott $\mathrm{M}$, et al. Novel RT-ddPCR assays for simultaneous quantification of multiple noncoding and coding regions of SARS-CoV-2 RNA. J Virol Methods. 2021;292:114115.

22. Vasudevan HN, Xu P, Servellita V, Miller S, Liu L, Gopez A, et al. Digital droplet PCR accurately quantifies SARS-CoV-2 viral load from crude lysate without nucleic acid purification. Sci Rep. 2021;11(1):780.

23. Park C, Lee J, Hassan ZU, Ku KB, Kim SJ, Kim HG, et al. Comparison of digital PCR and quantitative PCR with various SARS-CoV-2primer-probe sets. J Microbiol Biotechnol. 2021;31(3):358-67.

24. Tedim AP, Almansa R, Domínguez-Gil M, González-Rivera M, Micheloud D, Ryan P, et al. Comparison of real-time and droplet digital PCR to detect and quantify SARS-CoV-2 RNA in plasma. European journal of clinical investigation. 2021:e13501.

25. Liu X, Feng J, Zhang Q, Guo D, Zhang L, Suo T, et al. Analytical comparisons of SARS-COV-2 detection by qRT-PCR and ddPCR with multiple primer/probe sets. Emerging microbes \& infections. 2020;9(1):1175-9.

26. Zhou H, Liu D, Ma L, Ma T, Xu T, Ren L, et al. A SARS-CoV-2 reference standard quantified by multiple digital PCR platforms for quality assessment of molecular tests. Anal Chem. 2021;93(2):71521.

27. Wu F, Zhao S, Yu B, Chen YM, Wang W, Song ZG, et al. A new coronavirus associated with human respiratory disease in China. Nature. 2020;579(7798):265-9.

28. Dong L, Meng Y, Sui Z, Wang J, Wu L, Fu B. Comparison of four digital PCR platforms for accurate quantification of DNA copy number of a certified plasmid DNA reference material. Scientific reports.2015;5:13174-13185.

29. CNAS. Guidance on statistic treatment of proficiency testing results and performance evaluation. 2018.

Publisher's note Springer Nature remains neutral with regard to jurisdictional claims in published maps and institutional affiliations.

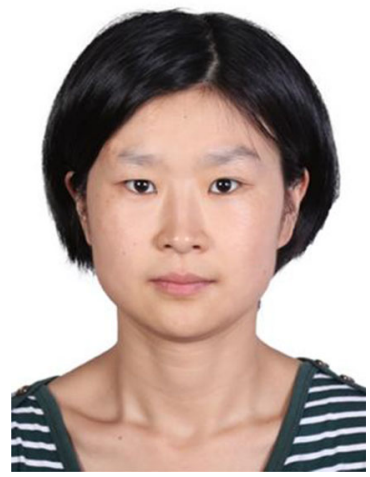

Chunyan Niu received her $\mathrm{PhD}$ degree in biochemistry and molecular biology from the University of Chinese Academy of Sciences in 2013. After working as Postdoctoral Researcher at the Institute of Biophysics, CAS, she is currently Associate Researcher at the National Institute of Metrology, China. Her work focuses on the development of accurate analysis technology and reference materials of nucleic acid related to human diseases.

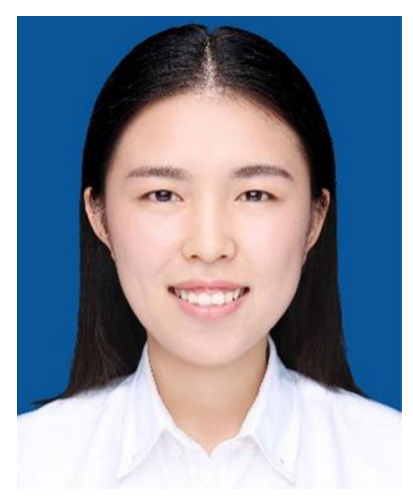

Xia Wang obtained her Master in Chemistry from the National Institute of Metrology (NIM) in 2020. She is now Research Assistant in nucleic acid metrology at the Center for Advanced Measurement Science of NIM, Beijing. She is currently working on studying the reference materials and biomarkers of genetic disorders using the absolute quantitative method in laboratory of nucleic acid metrology.

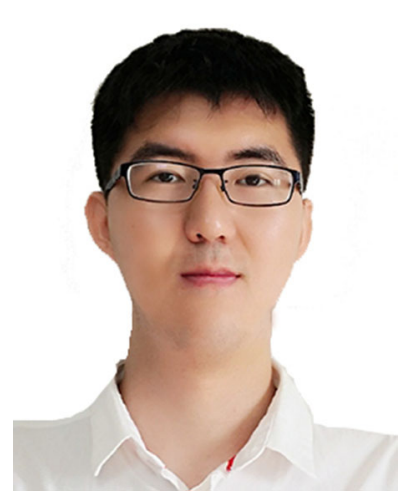

Yongzhuo Zhang received his $\mathrm{PhD}$ degree in Sciences in 2018. After working as Postdoctoral Researcher at the National Institute of Metrology, China (NIM), since 2019, he has been working at the nucleic acid group (NIM). He is a (co-)author of $>20$ peer-reviewed research papers, conference papers, and patents, and now he focuses on sequencing research, formulation of national calibration specifications, development of national reference materials, and other related work. 


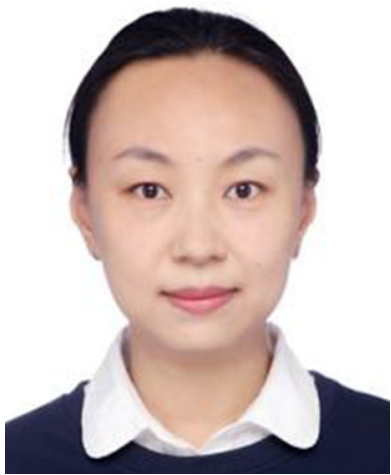

Lin Lu graduated from the Department of Medicine of Peking University in July 2003 with a bachelor's degree in medical laboratory, and in January 2012, she obtained her Master in Public Health from the Department of Medicine of Peking University. She began to work in the laboratory in 2003 and was once engaged in the research and application of visual gene chip nucleic acid detection technology. She is currently working in the Center for Reference Materials Research and Management.

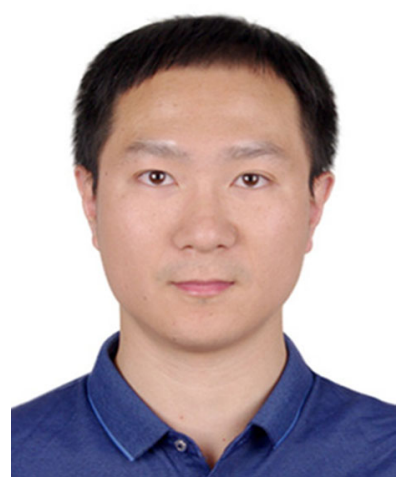

Di Wang is a postdoctoral researcher in the nucleic acid metrology team at the National Institute of Metrology, China. His research mainly focuses on the quantification measurement of nucleic acid samples using digital PCR or other methods. He is especially interested in singlemolecule counting technology based on the microfluidic system.

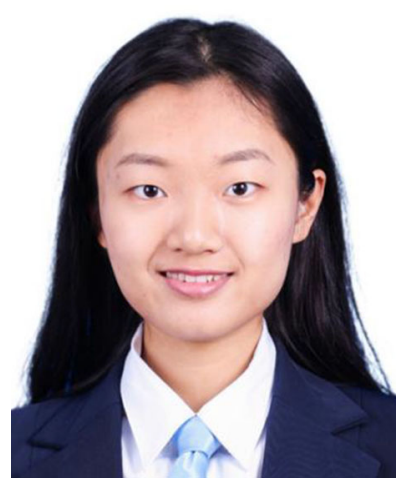

Shangjun Wang works as an engineer at the Nanjing Institute of Measurement and Testing Technology. Her research focuses on nucleic acid metrology, providing high-precision measurement for the biopharmaceutical industry.

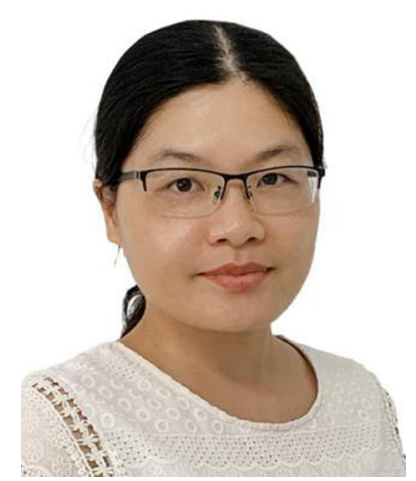

Jingyan Luo obtained her $\mathrm{PhD}$ degree in pharmacology from Sun Yat-sen University in 2012. She is now a R \& D Director of the Forevergen Biosciences Center (Guangdong Forevergen Medical Technology Co., Ltd, Foshan, China). Her current work focuses on the development of digital PCR assays and kits for numerous applications based on the MicroDrop ${ }^{\mathrm{TM}}$ digital PCR platform.

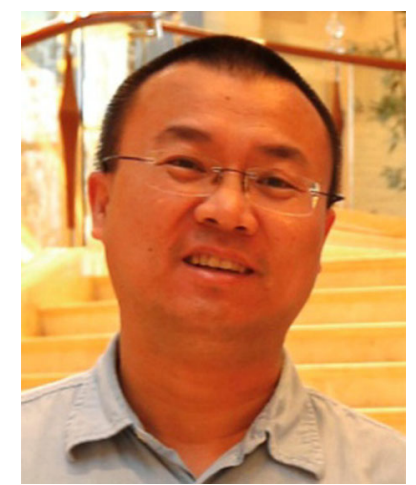

Ying Jiang received his Master's degree from the University of Pittsburgh. He is the co-founder and Research VP of Mission Medical Technologies (Ningbo) Co., Ltd, and has been working with digital PCR for many years. $\mathrm{He}$ is now leading a team to develop and commercialize tumor mutation and pathogen detection assays using digital PCR technology. 


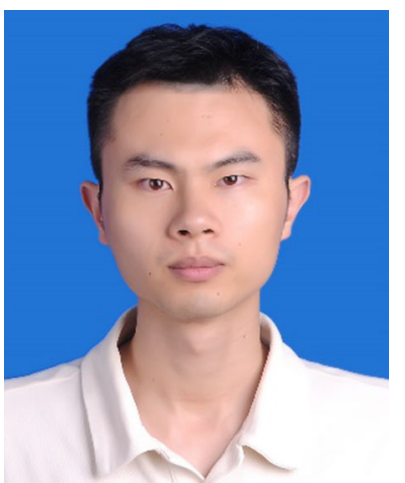

Nuo Wang comes from Wuhan Institute of Virology, CAS. His major is molecular biology.

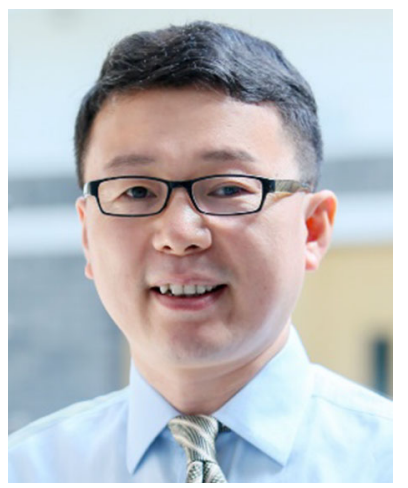

Yong Guo is Associate Professor in the Department of Biomedical Engineering at Tsinghua University. His research focuses on the investigation and development of molecular diagnostic technology, including digital PCR and microarray. He is an author or co-author of more than 40 scientific papers, as well as over 30 patents.

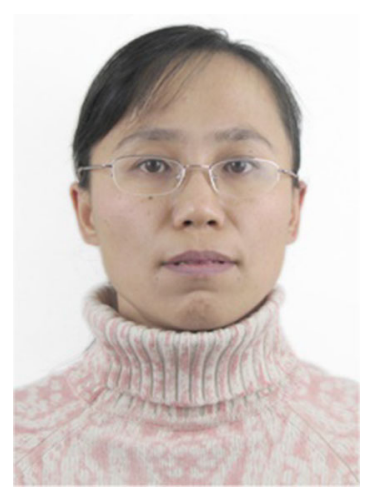

Lingxiang Zhu obtained her $\mathrm{PhD}$ in Biology from Tsinghua University in 2007. She is now Senior Researcher at the TargetingOne Corporation, Beijing, China. She is currently studying on diagnostic technologies and diagnostic kits for diseases.

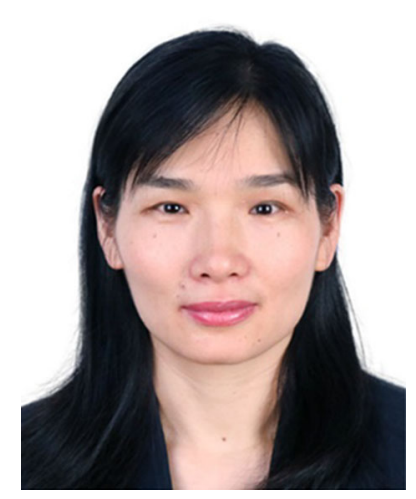

Lianhua Dong is Senior Researcher at the Research Center for Advanced Measurement Science (CAMS) in the National Institute of Metrology, China (NIM). She has led a team supporting the development of applied nucleic acid measurements in areas such as precision medicine, genetically modified organisms, and clinical microbiology at NIM. She won the APMP Young Metrologist Award 2020. She is an author or co-author of more than 40 scientific papers. 